\title{
The Way in Which Fee Reductions Influence Legal Aid Criminal Defence Lawyer Work: Insights from a Qualitative Study
}

\author{
JAMES THORNTON*
}

This article examines how fee reductions influence criminal defence lawyers' work. Data from 29 qualitative interviews with English defence solicitors and barristers are analysed in order to understand the way in which cuts to fees paid by government for criminal legal aid work can operate to influence criminal defence lawyers' working practices. I use game theory and Bourdieu's concepts of habitus and field to build a theoretical construct illustrating the invidious position current financial conditions place criminal legal aid lawyers in. I argue that these conditions reward and encourage perceived poor practices and values to thrive at the expense of other concerns - such as the conviction of the guilty, acquittal of the innocent, fair treatment of both victims and defendants, and value for the taxpayer. Ultimately, I argue that criminal legal aid lawyers are set up to fail by the current financial conditions within which they must work.

*Nottingham Law School, Nottingham Trent University, 50 Shakespeare Street, NG1 4FQ James.thornton@ntu.ac.uk

My sincere thanks to Mark Telford, David Gurnham, Jonathan Doak and the two anonymous peer reviewers for their very helpful comments on earlier drafts. I am also very grateful to my interviewees for taking the time to share their stories with me. 


\section{INTRODUCTION}

The fees paid by government for criminal defence work have been reduced many times over the years. The last increase of any sort was in $2007 .{ }^{1}$ Furthermore, changes to payment systems can cause indirect further reduction. ${ }^{2}$ Whilst some maintain that England and Wales has one of the most generous legal aid systems in the world, ${ }^{3}$ criminal lawyers themselves report a growing sense of crisis, resulting in industrial action and court challenges. ${ }^{4}$ This provides the opportunity to consider how criminal defence lawyers cope with cuts to fees in this context. This article analyses some findings from my own empirical research on this issue. ${ }^{5}$ The central question it seeks to address is how the practices of criminal legal aid lawyers are influenced by the limited financial context within which they must work. That question is itself underpinned by concerns about how to make sense of defence lawyers' own accounts of this in a critical, but fair, way. Hence, it builds upon recent empirical studies critiquing the practices of criminal legal aid lawyers and seeks to move beyond underlying conflicts that can be seen between them. Drawing on game theory and the Bourdieusian concepts of habitus, field and capital, the article proposes an original lens for understanding the empirical data of the current study and future socio-legal work. I first outline relevant features of how publicly funded defence lawyers are paid in England and Wales, before highlighting relevant studies that have conducted similar work. I next explain how I use Bourdieu's concepts, alongside my research methods. Discussion and analysis of this study's empirical data follows.

\section{CRIMINAL LEGAL AID PAYMENT SYSTEM IN ENGLAND AND WALES AND PREVIOUS RESEARCH}

Criminal defence advice and advocacy is mainly provided by the private sector. ${ }^{6}$ Solicitors firms make contracts with the Legal Aid Agency (LAA) to provide criminal defence services for specific parts of the country. Crown Court advocacy is paid for direct under a separate scheme. Both litigation and advocacy are generally paid in the form of fixed fees. Different fixed fees exist for different kinds of work, such as different kinds of offences and different outcomes (guilty plea vs trial and so forth). In some cases, that fixed fee will be increased if

\footnotetext{
${ }^{1}$ Criminal Defence Service (Funding) Order 2007 - for advocacy only. Solicitor fees stayed the same.

${ }^{2}$ See, for example, changes to emphasis placed on pages of prosecution evidence and the resulting judicial review: $R$ (Law Society) v Lord Chancellor [2018] EWHC 2094 (Admin).

${ }^{3}$ See, for example, then Justice Secretary Chris Grayling's foreword: 'Transforming Legal Aid: delivering a more credible and efficient system' CP14/2013.

${ }^{4}$ Criminal Bar Association Members Announcement 29/03/2018

<https://www.criminalbar.com/resources/news/announcement-for-cba-members>;

Law Society $v$ Lord Chancellor op. cit., n. 2.

5 J. Thornton, 'The Impact of Criminal Legal Aid Finance Reduction on the Work of Defence Lawyers' (2018) $\mathrm{PhD}$ thesis, University of Southampton.

${ }^{6}$ For a more detailed guide, see V. Ling et al., LAG Legal Aid Handbook (2013/14 - 2018/19 edns).
} 
the case crosses a complexity threshold. For example, the number of pages of prosecution evidence (PPE) and trial days allow Crown Court fees to "graduate" upwards. ${ }^{7}$

There are particular categories of legal aid work that are unconditionally free, for example, police station advice, however for other legal aid work - including trials - the lawyer must apply for a Representation Order. The client must satisfy two tests: income ("means") and interests of justice ("merits"). ${ }^{8}$ The former restricts the scheme to those whose earnings are below a certain level. The latter restricts the scheme to serious cases, by reference to statutory criteria. ${ }^{9}$ The merits test is automatically passed for Crown Court trials. ${ }^{10}$ A Crown Court Representation Order can be subject to a Contribution Order: requiring the defendant to pay a financial contribution, refunded if they are acquitted.

Much previous research has considered the work of defence lawyers. Two themes emerge:

1. Critiquing or defending the working practices of lawyers;

2. The effect of changes to lawyer payment structures (mainly focused on fixed fees vs hourly rates).

The latter includes quantitative work examining the introduction of new schemes at the macro-level. This study builds upon these two themes by examining the (related but separate) effect of cutting fees (rather than changes to payment structures per se), in the context of the changed payment structures identified by previous work in the second theme. In doing so, it also builds on the work of the first theme by providing an explanation for why some defence lawyers might behave in the way that they do.

As to the first theme, much previous work has reported negatively. McConville, et al.'s study of 48 defence firms ${ }^{11}$ found numerous examples of poor practice by defence lawyers, especially in pushing defendants towards guilty pleas. ${ }^{12}$ This built upon an earlier detailed study of police force areas, which also criticised the defence lawyers involved for abandoning all but the shell of adversariness". ${ }^{13}$ Mulcahy, in a study of two English magistrates' courts (consisting of pre-trial review observation and interviews with practitioners), found similarly negative influences. ${ }^{14}$ Lawyers were "acutely aware" of the financial disadvantages of trials, and this influenced the way they worked: to avoid them, in favour of negotiated settlements. ${ }^{15}$ Focusing on barristers, Morison and Leith's interview study found that because "time is

\footnotetext{
${ }^{7}$ PPE relevance for advocates has now been substantially reduced, but still plays a key part for assessing litigation work complexity. See: Criminal Legal Aid (Remuneration) Regulations 2013 Sch 1-2 (as amended).

${ }^{8}$ Legal Aid, Sentencing and Punishment of Offenders Act 2012 (LASPO), s17(1).

${ }^{9}$ Id.

10 '2017 Standard Crime Contract Specification' (Legal Aid Agency February 2017), clause 10.144.

${ }^{11}$ Standing Accused (1994) 15.

${ }^{12}$ Id., pp. 268, 210, 160.

${ }^{13}$ M. McConville et al., The Case for the Prosecution (1991) 168.

${ }^{14}$ A. Mulcahy, 'The Justifications of Justice: Legal Practitioners' Accounts of Negotiated Case Settlements in Magistrates Courts' (1994) 34 Brit. J. Criminology 411 at 415.

${ }^{15}$ Id., p. 412.
} 
short, and pressures are constant", ${ }^{16}$ they noted that cases were often poorly prepared. ${ }^{17}$ These studies supported similarly critical findings from the 70s onwards - including work from the Royal Commission on Criminal Justice, which branded its findings on police station work "disturbing". ${ }^{18}$ Although these studies are now somewhat dated, a more recent ethnographic and interview study carried out by Newman in three English criminal legal aid firms was also strongly critical. ${ }^{19}$ Participants "moved away from client-centeredness and towards managerial, profit centred concerns." ${ }^{20}$ Newman questioned the role of finance however: "the values that informed these lawyers should take centre stage over and above how they coped financially." 21 The most recent work on Crown Court advocacy, involving 46 trial judges (grouped by circuit) ${ }^{22}$ found that judges felt quality had declined and blamed finance reduction as a barrier to quality. ${ }^{23}$

In contrast, Travers' work reported positively on lawyer behaviour in his study. ${ }^{24}$ Likewise, Herbert, through observation, analysis of registers and 38 semi-structured interviews with magistrates court participants (including defence solicitors) found more benevolent behaviour. ${ }^{25}$ For example, tactically entering a not guilty plea, not for personal gain, but to force prosecution disclosure of information. ${ }^{26}$ A report by the Solicitors Regulation Authority (SRA) also recently considered the state of criminal defence firms, using surveys and interviews, and was broadly very positive - although it did identify some issues, for example, staff training. ${ }^{27}$ For barristers, Tague (having interviewed about changing to a fixed fee system) argued that, although lawyers may benefit from clients pleading not guilty in the Crown Court (for financial and career development reasons), ${ }^{28}$ this often aligns with client interests too. ${ }^{29}$

The key point here is that practitioner behaviour can be variable and can influence the criminal justice process. The current study builds upon this finding by examining one reason for this, namely: fee reduction, and its mechanism for influencing behaviour.

\footnotetext{
${ }^{16}$ J. Morison and P. Leith, The Barristers' World and the Nature of Law (1992) 91.

${ }^{17}$ Id., pp. 43-44.

${ }^{18}$ The Royal Commission on Criminal Justice Report (Cm 2263/1993) Para 59.

See: A.E. Bottoms and J.D. McClean, Defendants in the Criminal Process (1976);

J. Baldwin and M. McConville, Negotiated Justice (1977); J. Baldwin, Pre-trial Justice (1985); A. Sanders et al., 'Advice and Assistance at Police Stations and the Duty Solicitor Scheme' (Lord Chancellor's Department 1989); D. Dixon, 'Common sense, Legal Advice and the Right to Silence' [1991] Public Law 233; J. Hodgson, 'Adding Injury to Injustice : the suspect at the police station' (1994) $21 \mathrm{~J}$. of Law and Society 85.

${ }^{19}$ D. Newman, Legal Aid Lawyers and the Quest for Justice (2013) 30.

${ }^{20}$ Id., p. 159.

${ }^{21}$ Id., p. 158.

${ }^{22}$ Geographical criminal justice area. There are 6 across England and Wales.

${ }^{23}$ Hunter et al., 'Judicial Perceptions of the Quality of Criminal Advocacy' (2018), 4.1.

${ }^{24}$ M. Travers, The Reality of Law (1997)

${ }^{25}$ A. Herbert, 'Mode of Trial and Magistrates Sentencing Powers: Will Increased Powers Inevitably Lead to a Reduction in Committal Rate?' [2003] Criminal Law Rev. 314, at 316.

${ }^{26}$ Id., p. 321.

${ }^{27}$ Solicitors Regulation Authority, 'Criminal Advocacy Thematic Review' (2018).

${ }^{28}$ P. Tague 'Barristers' Selfish Incentives in Counselling Clients' [2008] Criminal Law Rev. 3, at 6, 12.

${ }^{29}$ P. Tague, 'Tactical Reasons for Recommending Trials Rather Than Guilty Pleas in the Crown Court [2006] Criminal Law Rev. 23, at 25.
} 
As to the second theme, Goriely et al.'s study looked at the introduction of a public defence solicitor's office in Scotland, alongside the traditional private sector firms being paid by public funding. A quantitative study of 2600 cases was carried out between April and December 1999, supplemented by 48 interviews with relevant actors, including lawyers. ${ }^{30} \mathrm{On}$ the basis of their data, they argued that behavioural changes were strongest in "ethical indeterminacy" situations: where several plausible choices of what to do in a case exist. ${ }^{31}$ The researchers involved would later reflect that this had concrete consequences: public defence solicitor's office lawyers resolved cases earlier than private ones. ${ }^{32}$ They concluded that solicitors were "routinely influenced" by financial incentives. ${ }^{33}$ Study of the introduction of fixed fees in Scotland similarly found that this had influenced the behaviour of practitioners (particularly in, as before, situations of "ethical indeterminacy"). ${ }^{34}$ For example, increasing volume of cases ${ }^{35}$, avoiding client support, ${ }^{36}$ avoiding interviewing witnesses ${ }^{37}$ and, because of systemic quirks at the time, pleading not guilty initially (to secure legal aid) and then guilty later on in the process. ${ }^{38}$ "almost none" of the lawyers involved said they were unaware of the most financially efficient way to deal with cases. ${ }^{39}$ Of course, as Tata later put it: lawyers don't always follow financial interest, but nor can they ignore finance, rather, finance is one factor among many other competing considerations. ${ }^{40}$ Somerland found similar in England, examining the impact of introducing fixed fees, she interviewed lawyers from 20 firms. ${ }^{41}$ Findings were not encouraging. As one interviewee put it: "Lawyers are learning to use the standard fees system and do very little for it." 42 Macro-level quantitative work has also considered these issues. Bevan carried out an analysis of the then government's claim that demand for legal aid is "supplier induced". ${ }^{43}$ In the criminal context, commenting on a drop in the volume of criminal work in the Crown Court or higher, Bevan noted that the unit cost (total spend, divided by number of acts of assistance) had increased in response. ${ }^{44}$ Similar work considered the impact of a finance change on defence lawyer behaviour (introduction of fixed fees). Gray et al. predicted a reduction in quantity or quality of work

\footnotetext{
${ }^{30}$ T. Goriely, et al., The Public Defence Solicitor's Office in Edinburgh: An Independent Evaluation (2001)

${ }^{31}$ Id., p. 69

${ }^{32}$ C. Tata et al., 'Does Mode of Delivery Make a Difference to Criminal Case Outcomes and Clients'

Satisfaction? The Public defence Solicitor Experiment' [2004] Criminal Law Rev. 120, at 127

${ }^{33}$ Id., p. 135.

${ }^{34}$ F. Stephen and C. Tata, Impact of the Introduction of Fixed Fee Payments into Summary Criminal Legal Aid : Report of an Independent Study (2007) 55.

35 Id., p. 29.

${ }^{36}$ Id., p. 38.

${ }^{37}$ Id., p. 40, in line with similar behaviour observed in England in the past: R. Young et al., In the Interests of Justice? (1992) 75-76.

${ }^{38}$ Id., p. 66.

${ }^{39}$ C. Tata and F. Stephen, 'Swings and Roundabouts: Do Changes to the Structure of Legal Aid Remuneration Make a Real Difference to Criminal Case Management and Case Outcomes?" [2006] Criminal Law Rev. 722, at 739.

${ }^{40}$ C. Tata, 'In the Interests of Clients or Commerce? Legal Aid, Supply, Demand and "Ethical Indeterminacy" in Criminal Defence Work' (2007) 34(4) J. of Law and Society 489, at 496.

${ }^{41}$ H. Somerland, 'Criminal Legal Aid Reforms and the Restructuring of Legal professionalism' in R. Young and

D. Wall (eds), Access to Criminal Justice: Legal Aid Lawyers and the Defence of Liberty (1996) 307.

${ }^{42}$ Id., pp. 310-311

${ }^{43}$ G. Bevan, 'Has there Been Supplier Induced Demand for Legal Aid?' (1996) 15(2) Civil Justice Q. 98.

${ }^{44}$ Id., p. 109.
} 
and little money being saved (due to lawyers playing the system). ${ }^{45}$ Later, Fenn et al.'s paper tested this hypothesis, using data from 1988-1994 legal aid bills (before and after fixed fees). They agreed: "solicitors do respond to financial incentives; something that economic theory recognises, and current/future reform should acknowledge". ${ }^{46}$ This supports the earlier theme's findings on practitioner power and willingness to influence case outcomes, but also makes the link between that and payment structure changes.

Again, it could be said these findings are out of date, but Welsh's more recent work also considered the impact of fixed fees (alongside means testing) on the work of solicitors in the magistrates court. Interviewing twelve defence lawyers (+ seven prosecutors) in South East England, alongside twenty days observation, the study confirmed that the introduction of fixed fees disincentivised work on cases. However, Welsh departed from the lawyer critique seen in the first theme. Her interviewees felt unhappily torn between duties to their clients and business needs. ${ }^{47}$

Hence, the previous work shows that defence lawyers can and have behaved in an allegedly poor way and negatively influenced the criminal justice process (as seen in the above examples from the literature). It also shows that this can be influenced by changes to the way defence lawyers are paid - for example, salaried public sector vs private sector and the movement towards payment by fixed fees. The current study adds to this by examining the effect of the similar, but distinct, change of lowering fee levels (in the context of the payment structures analysed in previous work). It also builds upon the analysis of lawyer behaviour seen in the first theme by both identifying current poor practices and providing a mechanism to explain how and why some lawyers may behave in this way.

The above research also shows a dichotomy between studies which, to a greater or lesser extent, paint lawyers in a positive light (for example, Travers, Welsh, SRA, Tague) and those which do not (for example, McConville, Newman, Somerland, Baldwin). Of course, the diverse set of views these individuals have are not as neat and tidy as such a broad division suggests: this approach requires a degree of crude generalisation. For example, later work by Newman shows him (as a researcher) struggling to reconcile the lawyer behaviour he observed with interview comments from those same lawyers, by looking at the matter from several different lenses. ${ }^{48}$ I am not suggesting that these researchers approach the issue from an unnuanced perspective. However, to typecast the studies in this general way does allow us

\footnotetext{
${ }^{45}$ A. Gray et al., 'Controlling lawyers' Costs Through Standard Fees: An Economic Analysis' in Young and Wall (eds) op. cit., n. 41, p. 215.

${ }^{46}$ P. Fenn et al., 'Standard Fees for Legal Aid, an Empirical Analysis of Incentives and Contracts' (2007) 59(4) Oxford Economic Papers 662, at p. 678.

${ }^{47}$ L. Welsh, 'The Effects of Changes to Legal Aid on Lawyers' Professional Identity and Behaviour in Summary Criminal Cases: A Case Study’ (2017) 44(4) J. of Law and Society 559, at 575-576.

${ }^{48}$ D. Newman, 'Are lawyers alienated workers?' (2016) 22 European J. of Current Legal Issues;

'Are lawyers neurotic?' (2018) 25(1) International J. of the Legal Profession 3; R. Dehaghani, and D. Newman " "We're vulnerable too": an (alternative) analysis of vulnerability within English criminal legal aid and police custody' (2017) 7(6) Oñati Socio-legal Series 1199.
} 
to consider two broad, conflicting, perspectives and the opportunity to move beyond such conflict with an alternative lens. The following section unpicks the nature of this tension in more detail, before outlining my own methods and how I seek to avoid it.

\section{METHODS OF ANALYSIS}

The disparity in judgment of defence lawyers noted above, particularly well exemplified by McConville et al. (who castigated their behaviour) ${ }^{49}$ and Travers ${ }^{50}$ (who complimented it) generated some robust discussion. Travers contended that other studies preached about morals and conduct from the assumed-to-be-privileged epistemological standpoint of the academy. ${ }^{51}$ Instead, Travers argued academics must first understand how subjects themselves view the world and the incidents under discussion, giving the example of his magistrates court observation. What seemed like "a lawyer using her position of power to persuade a vulnerable client to plead guilty" was actually a lawyer securing the best outcome, "in real time, and in full knowledge that, whatever she did" the defendant would have been convicted. ${ }^{52}$

Travers critiqued McConville et al's work along those lines and reliance on the "correspondence theory of truth": researchers claiming their version of the police and criminal defence lawyers reveals the "objective reality" of the process. ${ }^{53}$ In other words "structuralism" - the epistemological belief that there is an overarching objective structure, which, if only we can understand it, explains social phenomena. ${ }^{54}$ Fundamentally, this is an example of objectivism. Travers argued this can be viewed differently: under the "congruence theory of truth", "reality is a product of the way in which the observer describes it" and there are therefore multiple realities to consider. ${ }^{55}$ In other words, "interpretivism": there is no understandable objective structure per se - reality is a product of the way individuals experience it. ${ }^{56}$ Hence the argument that searching for abstract and generalist structures takes us away from "the richness of reality". ${ }^{57}$ Fundamentally, an example of

\footnotetext{
${ }^{49}$ Op. cit., n. 11.

${ }^{50}$ Op. cit., n. 24.

${ }^{51}$ Id., p. 157.

$52 \mathrm{Id}$.

${ }^{53}$ M. Travers, 'Preaching to the Converted? Improving the Persuasiveness of Criminal Justice Research' (2001)

37(3) Brit. J. Criminology 359, at 366.

${ }^{54}$ A.J. Ayer, Language, Truth and Logic (first published 1936, 2001) Exemplifies the extreme of this: if assertions are not verifiable by empirically observable reality, they are nonsense.

55 Travers, op. cit., n. 53, pp. 366-367.

${ }^{56}$ Newman, op. cit., n. 19, p. 26.

${ }^{57}$ M. Weber, "Objectivity" in Social Science' in M. Weber, On the Methodology of the Social Sciences (E.

Shils and H. Finch eds and trs), p. 80
} 
"subjectivism". Travers argued that McConville et al. dismissed ${ }^{58}$ this division's implications too readily. ${ }^{59}$ The result is that it is "remarkably easy" to criticise their findings. ${ }^{60}$

A robust defence was published in the same journal, ${ }^{61}$ labelling many of Travers' points "strange" and citing a passage from the authors' own study "because Travers seems not to have read it"... ${ }^{62}$ In essence, their approach was fine because, despite Travers' criticism, it produced "illuminating" findings. ${ }^{63}$ They also criticised Travers' approach as having "a risk of extreme relativism... accepting at face value practitioners' own rationalisations for their (mal)practices."64

Hence, researchers have a quandary: how to conduct and analyse research without blindly accepting lawyer participants' attempts to self-justify poor practice, ${ }^{65}$ but not unfairly judging from an academic pedestal. On the one hand, McConville et al. were entitled to describe their findings as "illuminating" because they were illuminating: they illustrated a previously unknown problem (and resulted in reforms, such as an accreditation scheme for police station legal advisers). However, Travers' critique, (that it is vulnerable to counter-attack, unfairly caricatures those involved and is unlikely to be persuasive to those whose behaviour it is seeking to change) also appears to ring true - with for example, Newman's recent research suggesting the behaviour of some defence lawyers has not improved many years later. ${ }^{66}$ This divergence continues to this day. As we saw, both Newman and Welsh did very similar things (they observed defence solicitors at work and interviewed them about it). Yet, Newman concluded that quite apart from finance, the lawyers simply did not regret their poor behaviour. ${ }^{67}$ Welsh referred to and then explicitly diverged from Newman's view, arguing her interviewees were torn between duties to clients and business needs. ${ }^{68}$

Newman attempted to escape this predicament, using Giddens" "structuration theory" 69 to produce an "integrated methodology" in his study of legal aid lawyers. ${ }^{70}$ This was a compromise between the many firms studied by McConville et al. and Travers' single study of one firm in depth. Newman did three months of ethnographic observation, and then interviews at three firms. Newman also made some important presentation changes to begin

\footnotetext{
${ }^{58}$ McConville et al., op. cit., n. 13, p. 13.

59 Travers, op. cit., n. 53, pp. 366-367.

60 id., p. 367.

${ }^{61}$ L. Bridges et al., 'Can Critical Research Influence Policy? A Response to Max Travers', (1997) 37(3) Brit. J. Criminology 378.

62 id., pp. 378, 380.

63 id., p. 380.

64 id., p. 379.

${ }^{65}$ Which the self-justifying individual themselves may be unaware of. See M. Lipsky, Street-Level Bureaucracy (1980) 153, outlining "cognitive shields" individuals use to rationalise malpractice.

${ }^{66}$ Newman, op. cit., n. 19, pp. 144-146.

${ }^{67}$ Id., pp. 86, 158.

${ }^{68}$ Welsh, op. cit., n. 47, pp. 576-577.

${ }^{69}$ A. Giddens, The Constitution of Society (1986).

${ }^{70}$ Newman, op. cit., n. 19, p. 27.
} 
to address the methodology problems he had identified: presenting data first with little comment, and then his commentary.

Nonetheless, Newman's conclusions were similarly critical to McConville et al. and similarly at odds with more sympathetic studies. I argue this is because, whilst the study did make changes to methods and some changes to methodology, such changes did not go far enough. Newman's solution focused firstly on methods, compromising between McConville et al.'s large number of (Travers would argue) shallower studies and Travers' in-depth single study and secondly on methodology, but only in so far as the way the analysis and data were presented or laid out. However, the way that data is analysed is just as important as its presentation. Travers pointed out previous researchers had used the same methods he used. The difference was "not method, but methodology." That being, "the different assumptions informing the collection and analysis of data" "71 (my emphasis). Hence, beyond changing the layout, this quandary requires a willingness to appreciate both perspectives of data.

I suggest that we can do so using Pierre Bourdieu's concepts of habitus, field and, capital and (crucially) the way they interact. This approach to both Bourdieu's concepts and the above issues provides a unique way to move beyond the above conflicts and an innovative lens with which to analyse and understand defence lawyer accounts in this area. I will briefly outline these in general before discussing how they apply to this issue. ${ }^{72}$ Bourdieu's work sets out to solve this "artificial" division between subjectivism and objectivism. ${ }^{73}$ In simple terms Bourdieu's argument is that people behave in the way they do because of the interaction between habitus, field and capital - which, together, take account of both the subjective and the objective perspectives discussed earlier. ${ }^{74}$

Habitus consists of "systems of durable, transposable dispositions, structured structures predisposed to function as structuring structures, that is, as principles which generate and organise practices and representations". ${ }^{75}$ Habitus is a "disposition" in the sense that it refers to someone's inherent qualities, which influence the way they behave. This disposition is "durable" because it can become self-perpetuating. Someone's habitus is influenced by the choices they make, but it also influences those choices as well: a "present past". ${ }^{76}$ Past experiences influence not only the choices we make in future, but also the choices we can comprehend. If, practically, someone has choices A-Z, their habitus may mean they can only comprehend choices A-E and are pre-disposed to particularly favour choices B and C. It is a "structured" structure in the sense that it is "structured" by a person's past experiences and the resulting structure is not random, but based on what has gone before. This structure is

\footnotetext{
${ }^{71}$ Travers, op. cit., n. 24, p. 14.

${ }^{72}$ For a detailed, multi-theorist, introductory analysis of Bourdieu, see: M. Grenfell (ed.), Pierre Bourdieu: Key Concepts ( $2^{\text {nd }}$ edn., 2014).

${ }^{73}$ P. Bourdieu, The Logic of Practice (Richard Nice tr., 1990) 23.

${ }^{74}$ Id. p. 23.

75 id. p. 53.

76 id. p. 54.
} 
itself "structuring" in the sense that it influences a person's future decisions (then forming a fresh part of their habitus).

Hence, habitus is a combination of what a person is inclined to do and an individual's subconscious understanding of how the world works - or rather, how their world works. This leads to the concept of field: someone's social environment. Bourdieu likens it to a game. The field is the "objective structures within which it is played out". ${ }^{77}$ This includes the pitch/board the game is played on and the field's territorial limits (each is a "separate universe governed by its own laws"). ${ }^{78}$ Fields range in size. For example, in Homo Academicus, Bourdieu analysed academia as a "field" 79 and contemporary society in The Weight of the World. ${ }^{80}$ The criminal justice process is our "field".

Individuals have positions within fields. This leads us to the concept of "capital": the way power in a field is measured. ${ }^{81}$ For Bourdieu, one element is money/assets: "economic capital". ${ }^{82}$ The other (often more important) element is "symbolic capital", 83 sometimes broken down into sub-groups, such as "social capital" (who an individual knows), or "cultural capital" (someone's taste and lifestyle). ${ }^{84}$ but in total it amounts to the tastes, values, lifestyle and so on of the dominant group's habitus in a given field. ${ }^{85}$

The interaction between habitus, field and capital explains someone's "practice". A crucial part of an individual's habitus is defined by reference to field: what Bourdieu calls a "feel for the game"- ${ }^{86}$ acclimatisation to how the world works in a particular field. This runs in both directions. The field influences a person's habitus, which helps ensure field longevity. It will be full of actors whose habitus is influenced and built for that field - it is in their interest to ensure the field stays that way. ${ }^{87}$ For example, in a corrupt country's criminal justice "field", a lawyer whose habitus aligned with those conditions would be accustomed to it. They may see possible actions for themselves (such as bribing judges) that someone outside that field would not - or if they did, would nonetheless decide not to do. The crooked lawyer has a "feel for the game" here. Habitus also influences the field, because the field's continued existence partly depends on the practices of those within it. If the habitus changes, the field itself can change. In this example, the crooked lawyers are themselves contributing to an environment of corruption and it is in their interests for that field to continue since their habitus allows them to flourish in it (this accustomed habitus is itself a potent form of

\footnotetext{
77 id. p. 66.

${ }^{78}$ P. Bourdieu, The Social Structures of the Economy (Chris Turner tr., 2005) 7.

${ }^{79}$ (Peter Collier tr., 1990).

80 (Priscilla Parkhurst Ferguson tr., 1999).

${ }^{81}$ P. Bourdieu, 'The Forms of Capital' in Handbook of Theory and Research for the Sociology of Education, ed.

J. Richardson (1986) 243.

${ }^{82}$ Id. p. 242.

${ }^{83}$ Bourdieu, op. cit., n. 73, p. 119.

${ }^{84}$ Bourdieu, op. cit., n. 81, p. 243.

${ }^{85}$ id., pp. 244-245.

86 id., p. 66.

${ }^{87}$ Bourdieu, op. cit., n. 73, p. 67.
} 
symbolic capital). Equally, if the field changes too much too quickly, those with a habitus too specialised to the original field may be unable to cope (a concept Bourdieu called "hysteresis"). ${ }^{88}$ For example, workers dealing with the "restructuring" of the western steel industry. ${ }^{89}$ Capital then measures an individual's power in a field, but this links back to habitus because a habitus suited to the field, a perfect "feel for the game", is itself the ultimate form of symbolic capital for that field.

Understanding the necessary interaction and relation between these concepts (the objective "field" and subjective "habitus") connects the subjective with the objective to come to a meaningful understanding of individuals' practices and escapes the above epistemological dichotomy. Both of these perspectives are vital pieces of the puzzle in trying to explain why defence lawyers in legal research studies behave in the way that they do. Hence, using the data, I sought to understand the relationship between the views and perspectives of defence lawyers and the environment within which they must work.

One potential objection remains. Whilst Bourdieu's habitus concept usefully draws attention to something significant and offers a way of thinking about that, it is abstract. ${ }^{90}$ It is difficult to specify that “this person's habitus is $\mathbf{X}$ and not $\mathbf{Y}$.". In our context, however, I argue we can illustrate it through a model of Rational Self-interest, based upon the game theory of Albert Tucker's "Prisoner's Dilemma”. In Tucker's hypothetical experiment, a prosecutor makes a deal with two guilty accomplices: if they implicate the other, the prosecutor will drop their charges, but their accomplice will be convicted and imprisoned for three years. If they both do this, then the prosecutor can convict both (but with credit for pleading guilty) and ensure they serve 2 years each. If neither gives in, the prosecutor will only be able to convict them both of a lesser offence: 1 year's imprisonment:

Prisoner A

Cooperate Betray

\begin{tabular}{|c|c|c|c|c|c|}
\hline$n$ ner $\mathrm{B}$ & Betray & $\begin{array}{l}\text { Prisoner A: } \\
3 \text { years }\end{array}$ & $\begin{array}{l}\text { Prisoner B: } \\
\text { free }\end{array}$ & $\begin{array}{l}\text { Prisoner A: } \\
2 \text { years }\end{array}$ & $\begin{array}{l}\text { Prisoner B } \\
2 \text { Years }\end{array}$ \\
\hline & Cooperate & $\begin{array}{l}\text { Prisoner A: } \\
1 \text { year }\end{array}$ & $\begin{array}{l}\text { Prisoner B: } \\
1 \text { year }\end{array}$ & $\begin{array}{l}\text { Prisoner A: } \\
\text { free }\end{array}$ & $\begin{array}{l}\text { Prisoner B } \\
3 \text { years }\end{array}$ \\
\hline
\end{tabular}

Cooperate $=$ "cooperate" with your accomplice

Betray $=$ implicate your accomplice

\footnotetext{
${ }^{88}$ Id., p. 62.

${ }^{89}$ Bourdieu, op. cit., n. 80, pp. 6-23.

${ }^{90} \mathrm{~K}$. Maton, 'Habitus' in Grenfell, op. cit., n. 72.
} 
A "purely rational" individual will always betray. For Prisoner A, if Prisoner B betrays, their best option is to also betray, minimising loss: 2 years imprisonment, not 3 . If Prisoner B cooperates, Prisoner A's best choice is still to betray, ensuring no time in prison at all, rather than one year. When both do inevitably take this view, they both end up in a worse position than if they had cooperated. The prosecutor is the real winner.

Of course, that does not mean that the prisoner's dilemma theory's outcome (that both individuals will always betray) is inevitable. The rational or natural response may be to betray all the time, but it does not have to be that way. There is much more to human decision making than self-interested logic. Many participants in empirical tests of the dilemma have demonstrated more altruistic behaviour than the theory suggests: real people do not always pick "betray". ${ }^{91}$ Nonetheless, it provides a useful way to view habitus in this context in a less abstract way. If an individual with a particular habitus would "betray" every time they were faced with this sort of choice, we can classify their habitus as having internalised values of rational self-interest. This provides a useful benchmark for the analysis that follows.

\section{THE CURRENT STUDY}

The research aimed to evaluate the extent to which fee reductions influenced defence lawyer behaviour in the current system, building on the previous work examining the influence of changes to the way lawyers are paid (as opposed to how much) and providing a mechanism for this influence.

A total of 29 participants took part in semi-structured interviews: 16 barristers (11 different chambers), 12 solicitors and 1 caseworker (12 different firms). Solicitor participants were recruited via an invitation letter sent to criminal legal aid firms listed by the LAA as undertaking criminal legal aid work in southern England. These were further encouraged to nominate colleagues whom they thought may be interested. One interviewee referred to a large Facebook group of practising criminal lawyers, whose administrators allowed a post asking for interested participants. Based on the comparatively much smaller pool of practising Criminal Barristers, ${ }^{92}$ a slightly different approach was taken. Letters were sent to the treasurers of each of the four Inns of Court (every barrister must join an Inn to qualify as a barrister) explaining the research and the need for participants. Three of the Inns responded and advertised the research to their members. A similar approach was taken with the Criminal Bar Association, who agreed to advertise the research in their weekly newsletter for several months. Further willing interviewees were located by the endeavours of personal and professional contacts working at the Bar. Interviews took place between late 2015 and early

\footnotetext{
91 T. Kiyonari et al., 'Social Exchange and Reciprocity: Confusion or a Heuristic?' (2000) 21(6) Evolution and Human Behaviour 411.

${ }^{92}$ The Bar Standards Board estimated around 5000 barristers specialise in criminal law (compared with 2,262 solicitors firms) - Ministry of Justice, Litigators Graduated Fees Scheme and Court Appointees Equality Statement (2017) 3.
} 
2017. This would have allowed for some interesting analysis of changing perspectives over time, however, when comparing interviews, views were remarkably consistent.

Interviews were conducted either in-person or via telephone. Participants were asked openended questions about the impact of finance reduction on their work (in the context of recent and proposed cuts), general questions about the cases they had recently done, as well as more specific questions about finance reduction - often based upon things other interviewees had mentioned in order to triangulate claims. As Chan points out, "different accounts of the same phenomenon" are a useful cross-referencing tool. ${ }^{93}$ Questions about unethical behaviour were asked abstractly to avoid being personal (i.e. "Do you think others in your position might be tempted to do [socially frowned upon behaviour]?"94 In terms of transcripts, some changes were made for easier reading: for example, repeated words, filler discussion and interviewer replies of "yes", and so on are omitted. Italicised text within square brackets is a paraphrase of something an interviewee said (to save space). Non-italicised text in square brackets is to clarify how or what was said. Unique expressions were modified to preserve anonymity.

There are limits to this method. Whilst barrister interviewees were spread out, the solicitor interviews were carried out primarily in the south, (albeit there were some from outside this area) and it nonetheless represents a small percentage of criminal practitioners in England and Wales. These findings are not generalisable across the country. Rather, they show what is capable of happening, and has happened, amongst a set of lawyers in various locations, firms and chambers, and at many different levels of experience. Such findings are valid, dependable, ${ }^{95}$ and generalisable in terms of, as Peräkylä put it when interviewing counselling professionals, what those who were not included in the study could do - given that they have similar options available to them. ${ }^{96}$

There is also a conceptual limit in terms of how to (normatively) judge the quality of defence work described here in itself. Much of the following discussion considers issues and examples which interviewees themselves considered "poor practice". However, the extent to which this genuinely reflects the objective reality of the situation is unknown. What constitutes "good" and "poor" practice is greatly debateable. For example (as mentioned earlier), one of Travers' lawyers persuaded a vulnerable client to plead guilty, ${ }^{97}$ but if conviction was inevitable (as that lawyer believed) one could argue the best possible result was achieved. Others would say that "good practice" in that situation means fighting the case

\footnotetext{
93 J. Chan, Doing Less Time: Penal Reform in Crisis (1992) 19.

${ }^{94}$ B. Berg and H. Lune, Qualitative Research Methods in the Social Sciences $\left(8^{\text {th }} \mathrm{ed}, 2012\right) 125$.

${ }^{95}$ L. Webley, 'Qualitative Approaches to Empirical Legal Research' in The Oxford Handbook of Empirical Legal Studies, eds. P. Cane and H. Kiritzer (2010) 934-935.

${ }^{96}$ A. Peräkylä, 'Reliability and Validity in Research Based on Naturally Occurring Social Interaction' in Qualitative Research: Theory, Method and Practice, ed. D. Silverman (2004, $2^{\text {nd }}$ edn.) 297.

97 Travers, op. cit., n. 24, p. 121.
} 
to the bitter end..$^{98}$ Some view good lawyering as that which provides greatest assistance to the court, whereas others argue strongly against this. ${ }^{99}$ Some argue that getting what the client ultimately wants is what good lawyering is. The client decides the "destination" and the lawyer must find the best route. ${ }^{100}$ Even this raises problems though: as Tata argues, wishing to, for example, "get off", can mean a number of different things: reduced charge, reduced sentence, complete acquittal etc. ${ }^{101}$ "What is deemed to be favourable to the client ('get off') can only be understood in terms of clients' (managed) expectations." 102 Broader analysis of law and the work of lawyers would also critique the assumption that "lawyering in itself" is good. ${ }^{103}$ Cain considers that there can instead be "serious questioning" of the assumption that law and lawyers as we know them are good things in themselves. ${ }^{104}$ These conceptual questions of what it means to be a "good" lawyer are hugely important. However, they cannot be answered by this study (other than to provide examples of what a selection of lawyers think it is and is not). Nevertheless, the research does reveal whether interviewees feel the need to do things that they believe are not conducive to good defence work. Findings on this point can still themselves be insightful in understanding how fee reductions affect the work of defence lawyers, even though ultimately whether the implications of such findings are normatively 'good' or 'bad' is debateable.

\section{FINDINGS AND ANALYSIS}

Interviewees highlighted 3 key issues in which reduced finance played a part:

1. Advice on plea (both guilty and not guilty)

2. Junk and Golden cases

3. Thorough working

As will become apparent, there are two interrelated aspects of finance to each of these issues. Firstly, the payment structure itself (how fees are calculated for particular work) arguably sets up all three of these issues. In that sense, what follows reinforces previous work on the issue of fixed fees etc. and provides more recent examples of its operation. Secondly though, the reduction in rates in terms of absolute level of income (I used to get paid X for doing this item of work, but now it is Y\% less) is also a frequent feature in the interviewee accounts of these three issues. The research therefore focuses on the influence of absolute level fee reductions in the context of the overall payments regime. Both of these combined appear to be

\footnotetext{
${ }^{98}$ See, for example, comments in a focus group of defendants about how they choose their lawyer by Transform Justice: "Bringing everything up to that judge, to fight your corner. He didn't do any of that. I could have stood there myself and fought my own case... He didn't listen to me. (F3)".

${ }^{99}$ T. Smith, 'The "Quiet Revolution" in Criminal Defence: How the Zealous Advocate Slipped into the Shadow' (2013) 20(1) International J. of the Legal Profession 111.

${ }^{100}$ M. Cain, 'The General Practice Lawyer and the Client: towards a radical conception' (1979) 7 International J. of the Sociology of Law 331.

${ }^{101}$ Tata Op. Cit., n. 40, pp. 518-519, footnote 95.

${ }^{102} \mathrm{Id}$.

${ }^{103}$ M. Cain, 'The Symbol Traders' in Lawyers in a Postmodern World: Translation and Transgression, eds. M. Cain and C. Harrington (1994) 25.

${ }^{104}$ Id. 46-47.
} 
capable of making a difference to the way the lawyer involved views the situation they are in. Hence, the practical effect of cuts cannot be understood without reference to the payment regime and this is reflected in the interviewee comments.

For each of these issues, my point is not that defence lawyers always conduct themselves in the ways described below, but that the effect of finance reduction within this payment regime is to reward those who would and punish those who would not. In Bourdieusian terms, the habitus that is most aligned to this field (in other words, that has the highest level of capitalthat is, the most useful disposition to possess) is that which is predisposed to do so. If habitus is how an individual sees their world and is inclined to behave in it, then the habitus which the current field (the legal aid criminal defence market) rewards here is that which both sees the opportunities presented below and is willing to act on them. As pointed out earlier, habitus, field and capital are all interrelated. A habitus in-tune with the field is valuable capital (the measure of an individual's power in a field) because it allows an individual to succeed in that field, in much the same way that an elite footballer's "feel for the game" sets them apart from the amateur in terms of sporting success on the football field. As we shall see, the trouble here is that, rather than practitioner excellence, a different kind of habitus is rewarded in our field: one that accords with our model of rational self-interest, based upon Tucker's betraying prisoner.

\section{Advice on Plea}

Incentives here do not point in one direction. Rather, sometimes it was in interviewees' interests to encourage guilty pleas and sometimes to encourage not-guilty pleas.

Interviewees gave many examples where they felt financially pressured to run cases to trial and also felt that influencing the process in this way was not difficult. For example, Solicitor $\mathrm{C}$ and Barrister K.

\section{Solicitor C:}

If you've got a big case in the Crown Court, you're gonna make a big fee out of it on a not guilty. If it's a guilty plea, you're not. So it's not a very difficult exercise to persuade a client, to say, "well, it looks a bit difficult, but I think we've got a good run here! I think we should run it!" Even though it might be very much in people's [clients'] interests to say "early guilty plea first opportunity in the Crown Court, maximum mitigation, and maximum discount on the sentence”, but it means a reduction in fee.

\section{Barrister K:}

You know exactly what everything's worth. And there are times, well, put it this way: there's someone who says they want to plead guilty; I would never persuade them to 
plead not guilty, even if it was in my financial interest. But if they're not very sure, I will outline the two scenarios: this will happen if you plead guilty, that will happen if you plead not guilty, which is normal advice, but I probably wouldn't seek to persuade them to plead one way or the other if it wasn't in my financial interest. Although I would never persuade anyone out of acting against my interests, I probably wouldn't persuade them into it.

These views support the Scottish studies' findings on "ethical indeterminacy": where the choice is between two courses of action, both of which have advantages and disadvantages, greater weight is placed on the advantages that flow from a course of action that is in one's own interests. Less weight is placed on those that flow from actions that run contrary to one's interests." 105 Barrister K's comments relate to a situation where the choice between pleas is very finely balanced. In such a situation, they admit, the greater weight is placed on their own interests. The trouble of course is that the more fees are cut, the more financial pressure there is and the more heavily it will weigh towards self-interest in these situations. Furthermore, Stephen and Tata argue, "the simple distinction between [client] "instructions" and [lawyer] "advice" is less clear-cut than these terms suggest". ${ }^{106}$ As mentioned previously, clients do not always provide clear instructions and lawyer advice can sometimes be robust. ${ }^{107}$

Few said this impacted their own advice, but this again illustrates how the field can reward what the lawyer involved views as "poor practice" (by prioritising rational self-interest) and vice versa punish "good practice". The habitus of value here, is that which prioritises those concerns of rational self-interest (illustrated by Tucker's hypothetical prisoner). This opportunity exists because of the different fixed fees available for this kind of work, relative to the actual time it will take to do. In that sense, it relates to the payment structure itself. For Barrister E (amongst others), it is the combination of this field condition and the further condition of direct reduction in fees paid that influences here.

Barrister E:

you're conscious when you've got a case which represents a certain sum of money, and there aren't that many cases like that around anymore, because the cuts and because more work is going in-house ${ }^{108}$ and so you're looking at where you're less willing to give up what that case might be should it go to trial.

In other situations, it was in a lawyer's financial interest for clients to plead guilty.

For example,

\footnotetext{
105 Goriely et al., op. cit., n. 30, pp. 68-69.

106 Stephen and Tata, op. cit., n. 34, p. 56.

107 Tata, op. cit., n. 40, pp. 518-519, footnote 95.

${ }^{108}$ Sir Bill Jeffrey, Independent Criminal Advocacy in England and Wales (2014) 5, 19 found a $20 \%$ increase in in-house work from 2005/6-2012/13.
} 
Solicitor A: It's in your commercial interest on occasion to get a client to plead guilty. Lots of small hearings, associated with the orderly preparation of the case, attract a fee of $£ 75$ and that includes travel to the court and so you can have a short case that actually takes up all day (because you have your place in the queue) that pays $£ 75$ ! So it is not in your interest for those hearings to take place.

In a forthright ${ }^{109}$ answer to my question of whether this went on, they said it did:

All the time! People calculate that pleading guilty will benefit the lawyer best commercially and it gets justified on the basis that the evidence says that, despite his denials, he's probably guilty and even if he's not he's probably going to be convicted, so he'll do better with a third off for an early plea of guilty. ${ }^{110}$ I've seen it on a daily basis that clients are pressured into pleading guilty.

Morison and Leith heard this argument from barristers as well, with one interviewee stating "while you can't force him to plead guilty, there is often good reason for him to plead guilty for his own benefit." 111 Again, this is a combination of two field conditions: the payment regime in itself (which allocates relatively different fees for guilty and not guilty work in particular contexts) and absolute reductions in those fees themselves. The habitus that accords with Tucker's rational prisoner appears to be most valuable in this context.

Solicitor $\mathrm{H}$ and Barrister $\mathrm{O}$ illustrate this dual operation of payment structure and fee reduction:

Solicitor H: if I'm in my local magistrates' court on a Monday morning and I've got three cases to do, then I'll break even, but if I still have to be there for one case, then I won't - and one case can take as much time as three. You're working on very reduced fees and every time they chop at it, it makes you closer to not being able to provide the service

Barrister O:

There are always instances where you could advise a client to plead guilty and it would be better for your bottom line, but your professional integrity says you don't do that. I'm not saying this is something that's recent in terms of the dilemma itself - it's always been there - but these further cuts in legal aid have made it more likely.

\footnotetext{
${ }^{109}$ Perhaps because they had recently given up criminal law.

${ }^{110}$ Arguably another example of ethical indeterminacy.

${ }^{111}$ Morison and Leith, op. cit., n. 16, p. 116.
} 
These comments support the view of lawyers being aware of the financial benefits (or not) of particular options, in line with Tata and Stephen's and Mulcahy's earlier findings. ${ }^{112}$ How much this operates in reality is unclear. Certainly previous research and these interviewee comments suggest it is something a lawyer is capable of doing. As Morison and Leith point out, managing one's time (and ensuring one is doing the right case at the right time) is a key skill of the barrister. ${ }^{113}$ One interviewee pointed out that a quick guilty plea is one way of doing this, ${ }^{114}$ with many of their other respondents (as here) describing unscrupulous colleagues forcing clients into pleading guilty for financial reasons. ${ }^{115}$ Likewise Baldwin's early work provides a multitude of examples of defence lawyers "talking sense" into their clients ${ }^{116}$ and few of the lawyers in that study anticipated serious difficulty in doing so. ${ }^{117}$ The comments here are also quite consistent with Baldwin and McConville's defendant interviewee references to lawyers pulling "a fast one" "to get it over with". ${ }^{118}$ Mulcahy's observation illustrates the same phenomenon. ${ }^{119}$ One reason why lawyers would want to do that today is, as we have seen, financial pressure.

Some interviewees spoke in terms of cuts in legal aid making it "more likely" (e.g. Barrister O), whereas others more candidly stated it was going on (e.g. Solicitor A). Either way, such a setup favours the lawyer who is willing to do so and punishes those who do not, by making it very difficult to financially survive. In terms of our analysis of habitus and field, we can see that the habitus attuned to this field would be one that did so.

\section{2. 'Junk' and 'Golden' Cases}

'Junk' and 'golden' cases are those at the extreme ends of the fixed payment scale: situations where it would be financially self-defeating for the lawyer involved to take a case (junk cases) vs cases that are so remunerative that they could be the difference between having a profit and not (golden cases). Whilst any fixed fees system can expect slightly anomalous results relative to the actual work spent on a case, these should eventually balance. This is a feature of the payment regime, but reduction in finance raises the stakes of getting and keeping golden cases and getting rid of or avoiding junk ones. The combination of these two field conditions creates a unique field. For example, Solicitor $\mathrm{G}$ said that their firm only made a profit in a recent year thanks to two high paying Crown Court cases.

Solicitor B (amongst others) considered all magistrates and police station work was generally unprofitable: If you had no Crown Court cases in a six-month period you would go out of

\footnotetext{
112 Tata and Stephen, op. cit., n. 39, p. 739; Mulcahy, op. cit., n. 14, p. 412.

${ }^{113}$ Morison and Leith, op. cit., n. 16, p. 19.

${ }^{114}$ Id., p. 132.

115 Id., p. 120.

${ }^{116}$ Baldwin, op. cit., n. 18, p. 86.

${ }^{117}$ Id., p. 89.

118 Baldwin and McConville, op. cit., n. 18, p. 51.

${ }^{119}$ Mulcahy, op. cit., n. 14, p. 424. One solicitor requested the police organise an identity parade, so their client could be identified, see sense and plead guilty!
} 
business. Solicitor B did this as a loss leader (police station clients arrested for serious offences may retain services in the Crown Court) and as a source of cash flow.

There were exceptions to this though. Solicitor $\mathrm{C}$ dealt with the issue of certain clients being golden:

I've got a particular client who's now on case number 215 [with me]. He's subject to several different ASBOs and [example of how every now and then he breaches the ASBO] and he probably gets 4 cases a year now. Every now and again he'll try and get off one, but 9/10 he's in the magistrates court, it's a guilty plea. Thursday night: offence. Guilty plea: Friday morning. 15-30 mins work: £190. So it came out well!

Conversely, some clients were most undesirable, related to their likelihood of being granted legal aid. Many mentioned the self-employed, who would struggle to apply for legal aid and were therefore at an unwelcome risk of failing the means test for legal aid (meaning their lawyer would not be paid at all), but the same was also said regarding likelihood of success with the merits test too.

Solicitor D gave the example of two hypothetical shoplifting clients:

[if] all he's gonna get is a fine or a conditional discharge, you might think "If they're not granted legal aid, the time I spent on his case is wasted." [On the other hand] let's assume he's got a terrible record and he's kept in custody, or even better he's on a suspended sentence, then you think to yourself "well I've got a pretty much guaranteed legal aid order here”. So you're ideal shoplifting client is somebody who's in receipt of income support [easy to prove means test], on a suspended sentence, in custody [easy to pass merits test].

In that example it is the same crime, but with different clients the work can be junk or golden. This small selection of examples interviewees gave illustrates how a case can be a junk or a golden one for the most arbitrary of reasons. This reflects Kemp's ${ }^{120}$ and Welsh's ${ }^{121}$ later findings on the risks of representing some clients and then not getting paid. Welsh found that some lawyers represented these for free. ${ }^{122}$ However, the appetite for this decreases when fees reduce. As Solicitor H put it: Your good will, your, sort of, slack and wiggle room, is compromised considerably when the fees are cut. Whilst there may be other reasons for working pro bono, such as maintaining good relationships with other actors in the process, ${ }^{123}$ this too has its limits. Barrister $\mathrm{J}$, for example, managed to drastically cut down on a category of case many regarded as unprofitable, ${ }^{124}$ whilst still maintaining goodwill with their

\footnotetext{
${ }^{120}$ V. Kemp, Transforming Legal Aid: Access to Criminal Defence Services (2010) 70-71.

${ }^{121}$ Welsh, op. cit., n. 47, p. 567.

${ }^{122}$ Id., p. 579.

123 Id.

${ }^{124}$ Where the defendant elects Crown Court trial and then changes their mind on the day by pleading guilty.
} 
solicitors. The combined field conditions of the payments regime and lower fees generally again suggest that the habitus which flourishes within it is one which would maximise gold cases and minimise junk ones.

The choice of the lawyer involved here is not quite that simple though. Interviewees reported a number of responses to these sorts of cases short of simply dropping them. For example, some junk cases not done out of goodwill were:

Barrister H: knocked down from someone who's more senior all the way down to someone who's low enough on the ladder that they need the experience and they'll take the case no matter what.

The problems are significant, as Barrister $\mathrm{H}$ reflected:

I have had a few cases where I'm sure that they were innocent and they probably needed, in a couple of cases, more senior counsel than me. And because of legal aid... I don't know if those kind of counsel are going to get the case

This is in line with Tague's view that junior barristers benefit from running trials to demonstrate their skills. ${ }^{125}$ This concern could equally operate as an incentive to accept complex cases from others that would otherwise be regarded (by those more senior) as junk cases. This allows very junior barristers to practise their skills and improve their CVs. Morison and Leith also noted cases "passing from hand to hand as their true nature is discovered until, at last, a difficult, unprofitable or poorly prepared case finds its way to a new barrister too lowly to pass it on further." ${ }^{126}$ It seems this practice lives on as a key part of the habitus for the lawyer who wishes to succeed in this field (though arguably this is better than no representation at all).

Another approach was to do them, but not very well. As Solicitor B put it when describing unprofitable magistrate court cases:

They're just seen as “£200 here, $£ 300$ there”. That’s the legal aid cuts writ-large in the sense that there isn't any incentive.

Solicitor D provided another example of how this might impact, using the hypothetical example of going back to the police station to observe identity parades in a golden murder case vs in a junk shoplifting case and also the effect of different clients:

You have to think, effectively, strategically about this. You have to think to yourself, "what's most cost effective?" To make sure that I'm doing what I'm required to do in

\footnotetext{
125 Tague, op. cit., n. 28, p. 6.

${ }^{126}$ Morison and Leith, op. cit., n. 16, p. 27.
} 
providing the appropriate level of service to the client, but not bankrupting the firm while I'm doing it...

You've also gotta think about the client. If it's a regular client, who gets arrested 3 or 4 times a year, that client's very important to your firm. So you've got to manage him, which means when he asks for somebody to come you've gotta go.

As with advice on plea, this phenomenon of some cases being worth considerably more than others is largely brought into existence by the payment regime (which specifies that $\mathrm{X}$ work attracts X fixed fee and Y work attracts Y fixed fee etc.) However, when this is combined with an absolute reduction in fees, the impact of the incentive is felt to be greater, as Solicitor D illustrates: You think to yourself "well it wasn't so bad last year, but this year I've got to do the same work and I've had my fee cut 17.5\%.". And it does mean that there are certain things, which in the old days you would do without thinking, nowadays you do think about quite hard.

There is an apparent state of conflict between the habitus encouraged by the state of the field (which resembles that of the Tucker's rationally self-interested prisoner) and the habitus some defence lawyers would prefer to have (having recognised encouragements towards what they considered "poor" practice). Whilst many experienced lawyers still do junk cases out of a sense of duty, when fees are cut, that which used to be done without question is now thought about quite hard, as Solicitor D pointed out. Indeed, Solicitor D's comment illustrates the shift in terms of habitus towards rational self-interest well. The defence lawyer that thrives (or survives) in this field, is the one that is prepared to avoid junk cases (which can be "junk" for all sorts of arbitrary reasons) and chase golden ones. Those who do not, struggle to make a profit.

\section{Thorough Working}

Some work, under the current fee system, was considered financially disadvantageous to do. This supports many of the findings of studies that have examined the impact of payment structures. The point I seek to illustrate here is how these problems are exacerbated by finance reduction.

Solicitor B considered this a general issue:

What's happening now is that you're getting what I would describe as bare minimum preparation. And it's very difficult to motivate yourself if you can get away with bare minimum preparation. Because again you're trying to maximise your fee earning capacity and that really is by picking and choosing what work you do. 
Likewise with barristers, even at the best of times, as Morison and Leith found, barristers avoided spending too much time on certain unprofitable activities (such as legal research). ${ }^{127}$

Many gave the example of considering unused material. This work is notionally included in the fixed fee, but the fee is the same no matter how thoroughly it is reviewed and the defence case statement incorporating those insights is prepared. Despite this being important work (one textbook considers its importance "cannot be overstated" 128 ) in practice the financial incentive is to spend as little time as possible. Barrister $G$ gave an example from their practice of how this might operate:

There was a couple of hundred hours-worth of CCTV footage which we then had to go to the police station to watch - myself and the solicitor. So we did that and it was very revealing. So those three days that we spent at a station in [city], we got absolutely nothing for even though it was vital to our client's case. Certainly it would have been in my financial interest to go to court somewhere else rather than going to the Police Station to watch the CCTV. I could have taken on other cases during those three days and made money.

Not everyone is going to be willing or financially able to work three days for free. Indeed, the efforts of Barrister $\mathrm{G}$ and their instructing solicitor in the police station are already going well beyond what was observed by others earlier, for example, Dixon ("often passive and unsupportive") ${ }^{129}$ and the Royal Commission ("disturbing") ${ }^{130}$ - in better financial times. Whilst this phenomenon is not unique to the legal profession, in most jobs there is little incentive to do less (except laziness). Whereas here, as Barrister G said, spending less time on one task, can mean more remunerative work is done in its place. This is partly to do with the payment regime (in that, for example, Barrister G's extra time spent at the police station is not taken into account in calculating the fee), but again, the reduction in fee level itself within this regime makes the stakes uniquely high here. As Solicitor E put it in relation to the same issue of unused material:

The tighter you cut the funding, the more pressure there is on everyone to cut corners and put your own interest first and they can say 'till the cows come home "well, you should put your clients' interests first", but when it's your own bread and butter and your firm's gonna go under...

The lawyers involved viewed spending a great deal of time on the unused as being "good practice", but to do so has a cost, perhaps fatal to firm solvency. The habitus that would succeed under these field conditions is not one that would pre-dispose somebody to do the work on the unused material thoroughly, but to spend as little time as possible on it - just like Tucker's rational prisoner. Unused material is just one example. Various other interviewees

\footnotetext{
${ }^{127}$ Morison and Leith, op. cit., n. 16, p. 91.

${ }^{128}$ M. Hannibal and L. Mountford, Criminal Litigation Handbook 2014-2015 (2014) 223.

${ }^{129}$ Dixon, op. cit., n. 18, p. 242.

${ }^{130}$ Report of the Royal Commission, op. cit., n. 18, para 59.
} 
made similar points in relation to appeals (from both magistrates' courts and Crown Court), staff training, assessing expert evidence and interviewing independent witnesses to events. In each case, as Solicitor A put it: "You either do the job properly and lose money or you don't do the job properly."

Sadly, this is reminiscent of Plotnikoff and Woolfson's findings on the matter of appeals for the Royal Commission, in the wake of several high profile miscarriages of justice, as far back as 1993 ! $25 \%$ of prisoners received no assistance from a lawyer within the 28 days after their conviction (significant, due to appeal time limits), ${ }^{131}$ alongside concerning qualitative comments. They blamed ignorance of the law and good practice guidelines, ${ }^{132}$ yet interviewee comments in the present study suggested that, for them, it was the combination of the payment system and fee reduction. This suggests the problem is now one of financial resources, rather than education, and again shows how the habitus that favours financial selfinterest is the most useful to have here. Likewise, the concerns about training support those raised in the SRA's recent thematic analysis on the same point ${ }^{133}$ and explain why some firms may struggle to do so. Interviewees wanted to put on training, but the financial context makes this difficult.

In general, this is a similar response to that found in the Scottish study on the introduction of fixed fees: less time is spent on unprofitable activity, such as interviewing witnesses. ${ }^{134}$ Interviewees here illustrate the same thing happening when rates are lowered. Every reaction here is to either do work for free (which, in this payment regime particularly, becomes more difficult as cuts bite) or to cut corners. Interviewees were clearly unhappy about this, but also appreciated the financial reality. The alternative, as with some of the interviewees, is to leave criminal law before being forced to do that. The field rewards those who cut corners and punishes those who do not.

\section{Habitus, Field and Rational Self-interest}

The habitus required to financially survive and thrive in this field is that of a person predisposed towards favouring their own finances above other considerations. This mindset (although hopefully not widespread) is rewarded, whilst other approaches are punished.

The comments discussed above suggest defence lawyers find themselves in a similarly invidious position to that of the prisoner in Tucker's thought experiment discussed earlier:

\footnotetext{
${ }^{131}$ J. Plotnikoff and R. Woolfson, Information and Advice for Prisoners about Grounds for Appeal and the Appeals Process (Royal Commission on Criminal Justice Research Study 18, 1993) 79.

132 Id., p. 115.

${ }^{133}$ Op. cit., n. 27 , pp. 58-60.

${ }^{134}$ Stephen and Tata, op. cit. n. 34, p. 40.
} 


\section{Classic Prisoner's Dilemma}

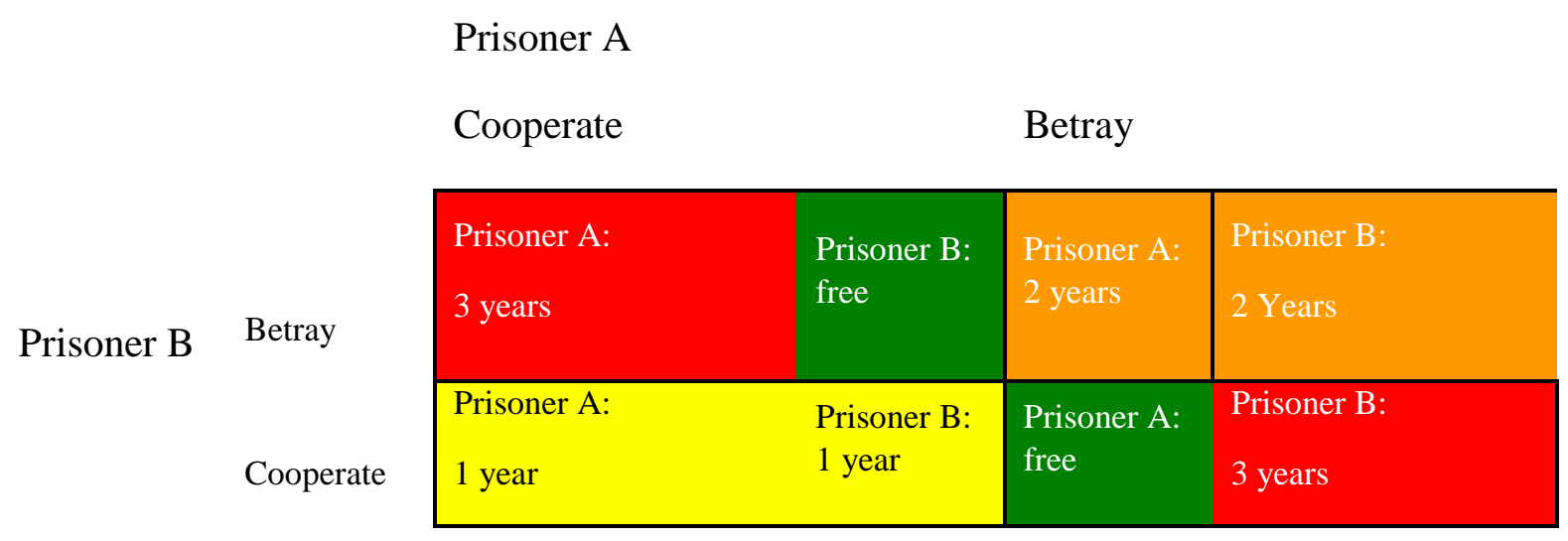

Cooperate $=$ "cooperate" with your accomplice

Betray $=$ implicate your accomplice

\section{Defence Lawyers' Dilemma}

\begin{tabular}{|c|c|c|c|c|c|}
\hline & & Ministry of $\mathrm{J}$ & ustice & & \\
\hline & & $\begin{array}{l}\text { Cooperate } \\
\text { (higher rates }\end{array}$ & & $\begin{array}{l}\text { Betray } \\
\text { (lower r }\end{array}$ & \\
\hline & $\begin{array}{l}\text { Betray } \\
\text { (follow financial } \\
\text { incentive) }\end{array}$ & Other Concerns & $\begin{array}{l}\text { Lawyer } \\
\text { Finance }\end{array}$ & $\begin{array}{l}\text { Other } \\
\text { Concerns }\end{array}$ & $\begin{array}{l}\text { Lawyer } \\
\text { Finance }\end{array}$ \\
\hline Lawyer & $\begin{array}{l}\text { Cooperate } \\
\text { (advise properly/take } \\
\text { junk case/investigate } \\
\text { thoroughly etc.) }\end{array}$ & Other Concerns & $\begin{array}{l}\text { Lawyer } \\
\text { Finance }\end{array}$ & $\begin{array}{l}\text { Other } \\
\text { Concerns }\end{array}$ & $\begin{array}{l}\text { Lawyer } \\
\text { Finance }\end{array}$ \\
\hline
\end{tabular}


In this diagram "Other Concerns" refers to the variety of (albeit sometimes conflicting) other objectives the criminal justice system is believed to have, although of course what these actually ought to be is a matter of intense debate. ${ }^{135}$

The particular context of the legal aid field means that the consequences are worse than the classic prisoner's dilemma. Classically, if both sides betray they end up in the second-worst state. Here, Other Concerns end up in their worst state, whenever the lawyer chooses betray, irrespective of the MoJ's choice. As noted when looking at previous studies, lawyers have the influence at this point. Conversely, again unlike the classic prisoner's dilemma, if both sides cooperate, instead of both achieving the second-best outcome, Other Concerns can achieve the best outcome for the same reason. Unlike the classic version, there is not necessarily any loss to Other Concerns by cooperating. This doesn't affect the choice: it is still in both side's self-interest to betray; it just worsens the consequences.

In that sense, this work provides a practical example of economists Fenn et al.'s argument: "solicitors do respond to financial incentives; something that economic theory recognises, and current/future reform should acknowledge." 136 The same can be said for changes in rates. Once we understand that lowering rates has the effect in this field that it does in incentivising a habitus entirely at odds with non-financial concerns, it should not be at all surprising if some lawyers behave this way. Game theory tells us this is the rational way to behave. Having the values of the Rational Self-interest model internalised as part of one's habitus, alongside the insider knowledge on how best to manipulate the system (and, based on the interviews, most lawyers clearly have this knowledge) rewards the defence lawyer in this field. Possessing this habitus is the ultimate form of symbolic capital. Those who do not will find themselves out of place and pressured to either leave or struggle to run a solvent business. This need not be something the individual lawyer is aware of either. Habitus is a somewhat sub-conscious "feel for the game". ${ }^{137}$ Analysing how overloaded public service workers process ever-larger numbers of clients, Lipsky noted the use of "cognitive shields". ${ }^{138}$ Practices can be blamed on systemic problems or clients themselves (for example, in our context, the financial pressures and the view that "he was always going to be convicted anyway" respectively), minimising personal responsibility. Whilst Lipsky accepts that these external factors do play a role, they do not mean individuals have no discretion at all. Such an individual could perceive their practices as good provided some clients are treated well: "there is no dissonance between the job as it should be done and the job as it is done for a certain portion of the clientele (original emphasis). ${ }^{139}$ Hence, even those with the best of intentions could possess such a habitus.

\footnotetext{
135 See above discussion in "The Current Study".

136 Op. cit. n. 46, p. 678.

${ }^{137}$ Bourdieu, op. cit, n 81, p. 66.

${ }^{138}$ Lipsky, op. cit., n. 65, p. 153.

${ }^{139}$ Id. p. $150-151$.
} 


\section{CONCLUSIONS}

The central question of this article was how the practices of criminal legal aid lawyers were influenced by the limited financial context within which they must work, necessarily underpinned by concerns about how to make sense of defence lawyers' own accounts of this in a critical, but fair, way. In relation to the question of influence, we have seen how the impoverished financial conditions of the current field put defence lawyers in something of a trap. The lower fees go, the more the habitus required to survive will resemble the Rational Self-interest model outlined. Yet, this is the kind of behaviour that many lawyers find distasteful. Nonetheless, game theory tells us that behaving otherwise is "irrational". On that basis, blame cannot exclusively lie with "shameful" defence lawyers, like some of those in Newman's ethnographic work. ${ }^{140}$ There may well be lawyers who have, like some of Newman's research subjects, "moved away from client-centeredness and towards managerial, profit-centred concerns", ${ }^{141}$ but even if they did have those client-centred values, the problem would remain. The trouble is that lawyers are operating in a field where the values of such a habitus are not conducive to success, whereas "managerial, profit-centred concerns" are. Much like Bourdieu's interviewees in The Weight of the World, such a habitus is out of sync with the field conditions and can only survive for so long. ${ }^{142}$ On that basis, Newman's overall critique is a little unkind. Calling for changes in legal education, lawyer self-reflection or other attempts to teach lawyers the correct values to hold, ${ }^{143}$ underestimates the influence that one's environment has on one's values and disposition - which the Bourdieusian field-habitus lens developed in this article allows us to appreciate. There is little point saying defence lawyers should have a particular habitus that contains the values I think are laudable, ${ }^{144}$ if it sets them up to fail in their field. The problem is both that the field does not accommodate (let alone encourage) lawyers who put their concerns about quality above concerns about finance and that some lawyers might put financial concerns first. Indeed, Bourdieu's point was that these two are interconnected: the field contributes to (or even creates) and internalises the habitus and the habitus maintains that field - they cannot be looked at in isolation. ${ }^{145}$ This new lens allows us to make sense of lawyer accounts (and therefore to understand a mechanism for how financial changes can influence defence lawyer work) in a way that is both critical, but fair. It is not unduly harsh on defence lawyers: through the concept of field, we can appreciate the context within which they must work. However, neither does it provide a blanket justification for putting financial concerns first: the concept of habitus recognises that individuals do have some control over their own decisions within the field, even if, as Lipsky's work suggests, some do not realise this. It was noted that one way of classifying the abstract concept of habitus was to construct a model of rational self-interest, based upon Tucker's hypothetical prisoner's dilemma. Favouring one's own concerns over others makes entirely logical sense in Tucker's example, as it does in many of the examples interviewees shared in this work. However, we also noted that this did not mean it had to be that way and that empirical tests of the dilemma demonstrate more

\footnotetext{
${ }^{140}$ Newman, op. cit., n. 19, p. 159.

${ }^{141} \mathrm{Id}$.

${ }^{142}$ Bourdieu, op. cit., n. 80. For example, pp. 6-23 on the Western steel industry.

${ }^{143}$ Newman, op. cit., n. 19, pp. 159-162.

${ }^{144}$ And what these should be is debateable.

145 Bourdieu, op. cit., n. 73, p. 67.
} 
altruistic behaviour than Tucker's theory would suggest. ${ }^{146}$ Not everyone betrays, no matter how much in one's interests it might be. Those lawyers who take a similar approach are to be commended, but we must also recognise that, under the current financial conditions, they are working heavily against their own interests in doing so. Hence, the Bourdieusian lens allow us the critical distance to appreciate the connection between context and the individual and how each can influence the other. The challenge for socio-legal scholars is to never lose sight of this connection and interaction in research. The challenge for policymakers is to avoid the temptation to see fee cuts as an easy solution for savings and, rather, appreciate the risks of financial self-interest-focused practice and inefficient working that this mechanism and the empirical data here suggests cuts can encourage.

${ }^{146}$ Kiyonari et al., op. cit., n. 91. 